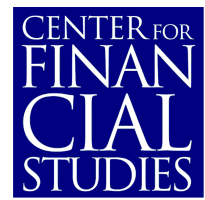

No. $2003 / 16$

\title{
The Role of Accounting in the German Financial System
}

Christian Leuz, Jens Wüstemann

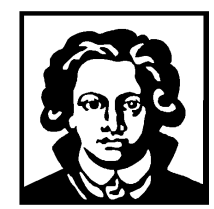




\title{
The Role of Accounting in the German Financial System
}

\author{
Christian Leuz*, Jens Wüstemann**
}

This version June 2003

\begin{abstract}
:
This chapter analyzes the role of financial accounting in the German financial system. It starts from the common perception that German accounting is rather "uninformative". This characterization is appropriate from the perspective of an arm's length or outside investor and when confined to the financial statements per se. But it is no longer accurate when a broader perspective is adopted. The German accounting system exhibits several arrangements that privately communicate information to insiders, notably the supervisory board. Due to these features, the key financing and contracting parties seem reasonably well informed. The same cannot be said about outside investors relying primarily on public disclosure. A descriptive analysis of the main elements of the Germany system and a survey of extant empirical accounting research generally support these arguments.
\end{abstract}

JEL Classification: M41, G3, D82, K0

Keywords: Accounting, Disclosure, Germany, Standards, Survey

* Wharton School, University of Pennsylvania.

** Business School, University of Mannheim.

Draft of Chapter 14 of the book "The German Financial System", edited by Jan P. Krahnen and Reinhard H.

Schmidt, forthcoming with Oxford University Press, London 2003. We thank Karl-Herrmann Fischer, Jan

Krahnen and Harry Schmidt for helpful comments on earlier versions. 


\section{INTRODUCTION: ACCOUNTING MYTHS}

Conventional wisdom has it that financial accounting in Germany is 'uninformative', or at least not as informative as in Anglo-American countries. The main complaints are that German accounting is very conservative, too heavily influenced by tax avoidance strategies, offers too much discretion allowing firms to build large hidden reserves, and lacks detailed disclosures. ${ }^{1}$ Although these characterizations may be correct, they generally evaluate German accounting and disclosure from the perspective of outside investors trading in public debt or equity markets and relying on publicly available information. In Germany, however, stock markets are comparatively small, corporate ownership is concentrated, and firms rely heavily on bank loans and other forms of private debt (Chapters 2, 5 and 10 of this book). Moreover, the above characterizations narrowly focus on the financial statements, i.e., on elements of the system that publicly disseminate information. They rarely consider institutional arrangements privately communicating information, such as the extensive German audit report ('Prüfungsbericht'), to which the attribute 'uninformative' certainly does not extend.

A country's accounting and disclosure system is part of its financial system and more generally its institutional infrastructure. Economic theory suggests that, in wellfunctioning economies, the elements of the institutional infrastructure evolve to fit and reinforce each other. Thus, the accounting system is likely to be geared towards the informational and contracting needs of the key parties in the economy. For this reason, it is important to understand the role of financial accounting in a country's

\footnotetext{
${ }^{1}$ See e.g., Investors Chronicle. 1994. Whose Bottom Line Is It Anyway? Financial Times Business Reports. 14 January 1994: 64; Evans. 1996. Brave New Welt: German companies finally become more shareholder-friendly; Barron's. 23 December 1996: 24; Review and Outlook (Editorial). 1997. Shake it Up. WSJ: A18.
} 
institutional infrastructure and, in particular, its role in corporate governance and capital markets. Thus, a key question in evaluating an accounting system is whether it satisfies the needs of the economy's main contracting parties and, in the context of financial systems, whether the relevant financing parties are well informed.

Using these questions as guiding principle, this chapter describes the main elements of the German financial accounting and disclosure system. We take a broader view and cover public as well as less-known private informational arrangements, which are integral parts of the German accounting system. We discuss the role of the various elements in the German financial system and analyze how they provide information to the key financing parties. Given the nature of the German financial system, which is often described as an 'insider system', we expect that information asymmetries are primarily resolved via private information channels rather than public disclosure. Thus, the accounting system likely exhibits elements that support insider governance and relationship-based contracting. Our institutional analysis confirms these expectations.

Due to the existence of private information channels, financial statements are less important in terms of monitoring economic performance and assume other roles, such as determining dividends. However, for this reason, arm's length or outside investors relying primarily on public disclosures are not as well informed in the German system as they are in Anglo-American economies. To support this claim, we survey empirical accounting research using German data. We argue that the findings are generally consistent with this hypothesis as well as several other expectations for the German accounting system.

The following section develops hypotheses about the role and properties of accounting in the German financial system. Section 3 describes the key elements of 
the German accounting system and ties them in with the financial system. Section 4 reviews empirical accounting research on Germany and discusses to what extent the findings are consistent with our hypotheses and the institutional analysis. The chapter concludes with a brief summary and some suggestions for future research.

\section{FINANCIAL ACCOUNTING AND THE INSTITUTIONAL FRAMEWORK}

In this section, we discuss the link between the accounting system and the institutional framework and, in particular, the financial system. We develop hypotheses about the properties of German accounting based on the idea that, in wellfunctioning economies, the elements of the institutional infrastructure evolve to fit each other. These hypotheses guide our institutional analysis and empirical survey in subsequent sections.

\section{Accounting and financial contracting}

Accounting information plays an important role in financial contracting (e.g. Watts and Zimmerman 1986). Financial claims and control rights are often defined in accounting terms. For instance, debt contracts use accounting numbers and financial ratios to specify when a corporate borrower is in default. In determining dividend payments to shareholders, firms frequently refer to past and current accounting earnings. Investors in public equity markets use financial statements to monitor their claims, make investment decisions or exercise their rights at shareholder meetings.

Given this role, it is reasonable to expect that accounting systems evolve such that they facilitate financial transactions and contracting. Moreover, standardizing accounting, either by regulation or private standard setting, is likely to reduce transaction costs. It seems cheaper to provide a common set of measurement rules for 
all or many contracts, rather than to negotiate a particular set of measurement rules on a contract-by-contract basis (e.g. Ball 2001). To capitalize on this effect, accounting standards are geared towards the informational and contracting needs of the key parties in an economy which are also likely to be the main lobbying parties (McLeay et al. 2000). That is, the accounting system is likely to reflect ownership and governance structures and the financing patterns in a country.

However, the properties of an existing accounting system can also shape financial contracting. A comparison of debt contracting in Germany and the US provides an illustrative example in this regard (Kübler 1989; Leuz 1996; Leuz et al. 1998; Wüstemann 1996, 1999 and 2002a). German accounting has traditionally been governed by 'prudence' and 'creditor protection', i.e., measurement rules that are favorable to creditors and limit payouts to shareholders. As a result, German debt contracts generally do not have extensive debt covenants restricting dividends to shareholders; they simply rely on the legal restrictions imposed by the accounting rules. In contrast, US-GAAP is not geared towards debt contracting. Not surprisingly, US debt contracts generally include extensive debt covenants, such as accountingbased payout restrictions, and in some cases even specify modifications of US-GAAP to take into account the needs of debt contracting.

In summary, the accounting system is a subsystem of the financial system interacting with the other subsystems (e.g. equity and credit markets, corporate governance). Ideally, the accounting system is complementary to the other elements of the institutional framework. ${ }^{2}$ This fit between the accounting system and a

\footnotetext{
2 Note, however, that we do not take a stance on the 'bigger' question whether the German system is efficient or not. We simply analyze whether German accounting informs the key parties in the system, taking other elements of the institutional structure as given, whether they are efficient or not.
} 
country's institutional infrastructure is likely to result in different accounting systems and informational regimes across countries.

\section{Stylized institutional frameworks and the role of accounting}

We illustrate the link between the accounting system and the other elements of the institutional infrastructure using two stylized financial systems. Following prior research, we distinguish between an 'arm's-length' or 'outsider' system and a 'relationship-based' or 'insider' system (Franks and Mayer 1994; Berglöf 1997; Schmidt and Tyrell 1997; Rajan and Zingales 1998; Allen and Gale 2000; Chapters 2 and 16 of this book). The two systems differ in the way they channel capital to investment opportunities, how they ensure a return to investors and, most importantly for our purposes, in the way they reduce information asymmetries between contracting and financing parties.

In an outsider system, firms rely heavily on public debt or equity markets in raising capital. Corporate ownership is dispersed and to a large extent in the hands of consumers that directly or indirectly via mutual funds invest their savings in public debt or equity markets. Investors are at arm's length from firms and do not have privileged access to information. They are protected by explicit contracts and extensive investor rights, which are enforced by the legal system (e.g. LaPorta et al. 1998). Public debt and equity markets and, in particular, the market for corporate control play a major role in monitoring managers and firms (e.g. Franks and Mayer 1994). Consequently, financial disclosure is crucial as it enables investors to monitor their financial claims and exercise their rights. Disclosure is also important for a wellfunctioning takeover market. Thus, in an outsider system, information asymmetries between firms and investors are primarily resolved via public disclosure (e.g. Ball et 
al. 2000). The accounting and disclosure system focuses on outside investors ensuring that they are reasonably well informed and, hence, willing to invest in the public debt and equity markets.

In contrast, in a relationship-based system, firms establish close relationships with banks and other financial intermediaries and rely heavily on internal financing, instead of raising capital in public equity or debt markets. Corporate ownership is generally concentrated and characterized by substantial cross holdings. Corporate governance is mainly in the hands of insiders with privileged access to information (e.g. board members). Given the nature of the system, information asymmetries are resolved primarily via private channels rather than public disclosure (e.g. Ball et al. 2000). Thus, the key contracting and financing parties are reasonably well informed, while outside investors face a lack of transparency. However, opacity is an important feature of the system because it provides barriers to entry and protects relationships from the threat of competition (e.g. Rajan and Zingales 1998). Opacity effectively grants the financing parties some monopoly power over the firm, which allows insiders to secure sufficient returns and in turn ensures insider financing to firms.

In this system, the role of accounting is not so much to publicly disseminate information, but to facilitate relationship-based financing, for instance, by limiting the claims of outside shareholders to dividends, which protects creditors and promotes internal financing. In essence, as insiders have privileged access to information through their relationships, accounting can take on other roles such as the determination or restriction of payouts. The accounting system is also likely to support private channels of information.

For these reasons, it is important to adopt a broader perspective when evaluating the overall performance of accounting systems. In insider economies, the key 
elements of the accounting system may not be those that publicly disseminate information (even though they have been the focus of international accounting research). A more complete assessment includes private information channels and contracting roles of accounting.

\section{Implications and hypotheses for German accounting}

As the previous characterizations were stylized, real financial systems generally do not fit them in all respects. However, the UK or US are typically viewed as good examples of an outsider or arm's-length system. Germany is often viewed as the prototype of a relationship-based or insider system. The German stock market is quite small in comparison to US or UK markets. The primary sources for German firms are internal and bank financing (e.g. pension liabilities, retained earnings, bank loans). Traditionally, firms have a close relationship with a bank, the so-called Hausbank. But banks not only play a major role in financing, they also control substantial equity stakes, either directly or indirectly through proxy voting. They are typically represented on the supervisory board ('Aufsichtsrat')-the main instrument of German corporate governance. Ownership is concentrated and many firms are still under the control of families. There are also substantial corporate cross holdings. Corporate governance and control are primarily in the hands of insiders. ${ }^{3}$

Given these features of the German financial system, the key financing parties are expected to have little demand for public information. Their role in the corporate governance provides them with privileged access to private information. We therefore

\footnotetext{
${ }^{3}$ See Franks and Mayer (1994), Hackethal and Schmidt (2000), Naumann (2000), and several chapters, of this book, especially chapters 10 by Erik Theissen on the role and size of financial markets, chapter 7 by Elsas and Krahnen on bank-client relationships, and chapters 2 and 3 by Schmidt on corporate governance and on financing patterns, for more detailed characterizations of Germany's financial system.
} 
expect the key financing parties to be reasonably well informed. Moreover, as much of the information is privately communicated, we expect the German disclosure system to be less developed than in outsider economies, i.e., disclosure levels to be relatively low and reported earnings to be less informative about firm performance. Consequently, outside investors are likely to be less informed than the key financing parties.

Traditionally, outside investors have not been at the center of the German accounting system. Rather, the system is expected to exhibit elements that support insider governance and relationship-based contracting. That is, the system is likely to include institutional arrangements that ensure that the key financing parties privately obtain the necessary information to exercise their control rights. We expect it to assume roles other than the public dissemination of information. Finally, the enforcement of accounting rules is expected to be a function of internal corporate governance rather than of market governance.

\section{Recent changes in Germany}

In recent years, several elements of the German institutional framework have been subject to major reforms such as the 1994 Securities Act or the 1998 Corporate Control and Transparency Act (Section 3 of this chapter; Nowak 2001b). These reforms suggest that the German financial system is moving towards an arm's-length system.

These changes can be explained in part by the immense financing needs of the German economy created by the reunification in 1990. Shortly after the reunification, 
Germany's total capital imports started to exceed its total capital exports. ${ }^{4}$ That is, after years of exporting capital, Germany became a net capital importer. This change implies that the German economy could no longer rely on the traditional sources of finance. As international capital markets are not relationship-based, German firms had to play by international rules and faced demands for reliable public information. The 1998 Raising of Equity Relief Act, which allowed German firms that are listed on an exchange to furnish internationally accepted accounting standards, could be viewed as a reflection of this demand. ${ }^{5}$

To what extend do these recent trends and reforms alter our preceding predictions for the German accounting system? In principle, they should work against our hypotheses. However, complementarities among the elements of the institutional framework make it unlikely that reforms take hold unless several other elements of the system are changed simultaneously (e.g. Ball, 2001; Schmidt and Spindler 2002). But complementarities in the infrastructure also imply that once a sufficient number of changes have been made there are strong economic forces to make the remaining ones.

Thus, although we are skeptical that recent changes substantially alter our predictions based on the traditional features of the German financial system, we consider this possibility in the subsequent institutional analysis and analyze whether recent changes have fundamentally altered the accounting system or the financial system's reliance on private information channels and insider governance.

\footnotetext{
${ }^{4}$ See Bundesbank Statistics, EU time series 4628 and 4629 (http://www.bundesbank.de). We estimate a simple time-series model and confirm that net capital flows are significantly negative in the years after the reunification, even after controlling for a time trend and lagged net capital flows.

${ }^{5}$ Even prior to this rule change, certain German firms that heavily relied on arm's-length financing, e.g., because of non-traditional ownership structures or large financing needs, had strong incentives to commit to more disclosure in order to compensate the information deficits of outside investors and to reduce the associated premium in the cost of capital (e.g. Leuz and Verrecchia 2000).
} 


\section{INSTITUTIONAL ANALYSIS}

In this section we describe the key institutional features of the German accounting and disclosure regulation, which are presently subject to marked changes. We identify the relevant accounting and disclosure rules and briefly compare them in their legal quality to US GAAP. Throughout this section it is not our intent to cover accounting and disclosure rules in detail, but rather to analyze their relevant economic characteristics with respect to our hypotheses. More specifically, we summarize the role of German financial accounting in restricting and ensuring payments to owners and in tax accounting. We describe the channels that supply the public debt and equity markets with information. But we also identify and describe important sources of private - as opposed to public_-information to key contracting parties, thereby putting unprivileged parties (e.g., outside investors) at an informational disadvantage. The section ends with an outline of German enforcement mechanisms.

\section{The relevant rules and standard setting institutions}

German accounting regulation in general is codified in the German Commercial Code ('Handelsgesetzbuch'-HGB-), which applies to all legal forms of economic undertakings such as corporations, partnerships and closed corporations. Important accounting principles are directly codified in the German Commercial Code, such as the principle of prudence, the realization principle, or the principle of timeliness. Those principles are of fundamental importance for the system of German Generally Accepted Accounting Principles ('Grundsätze ordnungsmäßiger Buchführung', German GAAP). The term 'German GAAP' is nevertheless broader. It encompasses all legal rules, principles, standards and norms that have to be applied by a company 
in the preparation of its financial statements. Unlike, for instance, in the United States these accounting rules govern purposes of corporation law as well as purposes of securities regulation. ${ }^{6}$

German GAAP are a legal concept which means that they are ultimately subject to legislation and jurisdiction. German courts established a long time ago that accounting practice has some relevance in determining sound accounting principles, but that, in case of conflict, accounting would be considered a normative rather than a positive issue. In a leading decision, Germany's Federal Tax Court of Appeals ('Bundesfinanzhof') stated as early as 1967 that, even though prevailing accounting practice could be considered in court, only practice leading to financial statements that are in conformity with the legally intended purpose of the stated accounting rules could become GAAP. ${ }^{7}$ The same applies to professional standards, such as accounting recommendations promulgated by the German Institute of Certified Public Accountants ('Institut der Wirtschaftsprüfer in Deutschland e. V.').

From a legal point of view, the accounting principles and standards established in court decisions are part of German GAAP. Put differently, German courts determine GAAP, whereas US courts have to decide whether professional accounting standards such as US GAAP are appropriate under the circumstances (Wüstemann 1999: 10ff.). In Germany, accounting principles are considered to be legal rules ('Rechtsnormen') and not professional standards ('Fachnormen'). Consequently, and in accordance with the German constitution, the determination of German GAAP is for the most part a matter of 'legal interpretations' (Ordelheide and Pfaff 1994: 87) and does not result

\footnotetext{
${ }^{6}$ See Siegel (1985) for a discussion of differences in state and federal regulation and Wüstemann (1999: 91 ff.) for a comparison with German regulation.

${ }^{7}$ Decision of the Federal Tax Court of Appeals on May 31, 1967 (I 208/63, BFHE 89, 191, 194).
} 
from the activities of private standard setting bodies such as the Financial Accounting Standards Board (FASB) or the International Accounting Standard Board (IASB). The codified accounting principles, which are of a rather general nature, are interpreted and developed further by the courts.

Over the last forty years, beginning with several leading decisions in the late sixties, courts reached a very high level of technical competence in accounting issues, which manifests itself in important journal articles by federal judges. In interpreting accounting rules, German courts have - in literally thousands of court rulingsestablished a system of sound accounting principles and detailed standards regarding the recognition and measurement of assets and liabilities (Beisse 1994; Euler 1996; Moxter 1985; Moxter 1999; Moxter 2003). This system minimizes legal risks and creates what could be called legal security ('Rechtssicherheit') - even in questions of detail.

For these reasons, simply looking into Germany's Commercial Code provides only a rudimentary picture of German GAAP, missing the entire body of accounting case law. This predominance of law in the field of accounting regulation distinguishes the way in which accounting standards are determined in Germany from that, e.g., in the United States.

\section{Recent trends and their relation to the existing accounting system}

Responding to the pressures of multinational corporations a new legislative initiative in 1998 (the 1998 Raising of Equity Relief Act) permitted listed corporations for the first time to apply 'internationally accepted accounting principles' instead of German GAAP for the preparation of group accounts. The intent of the legislation was to improve the ability of German multinationals to raise capital in the global equity markets. The law eliminated the burden of having to prepare two types 
of financial statements, one for purposes of SEC-filing and one according to the German GAAP. Legislation made clear that both US-standards (US GAAP) and International Accouting Standards (IAS) are regarded as internationally accepted accounting principles', leaving also open the possibility of an acceptance of other national accounting systems. Note, however, that de lege lata only consolidated accounts ('Konzernabschluss') can be prepared in conformity with US GAAP and IAS: The so called individual accounts ('Einzelabschluss') are prepared for purposes of corporation law (e.g. distributions) and tax accounting, whereas groups must additionally prepare consolidated accounts for information purposes. Thus, the application of IAS by a German corporation does not have legal consequences for its tax payments and distributions to shareholders. However, it is likely to have factual consequences on its distributions to shareholders.

It has to be emphasized that German accounting legislation is already the result of European harmonization efforts. To summarize very briefly, European Directives (particularly the $2^{\text {nd }}, 4^{\text {th }}$ and $7^{\text {th }}$ Council Directive) have harmonized accounting and disclosure in Europe, requiring national governments to transform the Directives into national law. In Germany, this transformation took place with the 1985 Reform Act ('Bilanzrichtlinien-Gesetz'). Despite these harmonization efforts, the Directives left national choices and much discretion in the transformation. Moreover, it is neither historically nor currently clear, how much harmonization and standardization the European Union intends in accounting and disclosure matters (Fresl 2000). Recently, the European Union adopted a Directive stipulating the use of IAS for the consolidated financial statements of all publicly traded companies. The rules will 
become effective for fiscal years beginning on or after January $1,2005 .^{8}$ Germany is - for the moment - one of the few European countries that accept internationally accepted accounting standards as a real substitute for national accounting standards (and not as a set of additional financial statements).

The legal character of German GAAP implies that only legislation and jurisdiction have, ultimately, the power to decide which accounting standards are to be applied. Nevertheless, the 1998 Corporate Control and Transparency Act established the German Accounting Standards Board (GASB). It is the function of this private standard setting body to advise the Ministry of Justice in matters relating to accounting issues and also to represent Germany in international private standard setting bodies such as the IASB. It also promulgates accounting standards for companies' group accounts which are presumed to be in conformity with the law, but in principle could be challenged in court because as professional standards they cannot claim the same authority as legal accounting rules. The GASB surely has an important function in the harmonization of international accounting standards with the goal of ultimately arriving at a globally accepted set of accounting standards. However-as in the United States (e.g. Metcalf 1977)—, the formulation of accounting standards by a group of organized users with obvious self-interests in the solution of accounting issues is not unquestioned.

So far, the GASB has issued 13 German Accounting Standards (GAS), covering mere disclosure issues (e.g. risk reporting, interim financial reporting, cash flow

\footnotetext{
${ }^{8}$ Article 9 of the Regulation (EC) No 1606/2002 of the European Parliament and of the Council of 19 July 2002 on the application of international accounting standards provides for an exception for 'companies ... whose securities are admitted to public trading in a non-member State and which, for that purpose, have been using internationally accepted standards since a financial year that started prior to the publication of this Regulation in the Official Journal of the European Communities'. This article applies, for instance, to corporations that are registered with the SEC and obliged to provide financial statements in conformity with US GAAP.
} 
statements, and segment reporting) and questions of recognition (e.g. accounting for investments in joint ventures in consolidated financial statements, non-current intangible assets). Given that the GASB took up its work only in 1998, it is still too early to pass judgment on the issues raised above. Furthermore, it is not quite clear whether there will even be a need for a traditional national standard setting body after the incorporation of IAS into European accounting law in 2005.

\section{The purposes of German accounting regulation}

German corporation law binds any distributions to owners to the existence of profits available for distribution in a company's individual accounts. The determination of distributable profits has to be in accordance with German GAAP. These legal rules are a transformation of the legal capital scheme laid down in the $2^{\text {nd }}$ European Directive into German law. However, the link between financial accounting and corporate distributions (e.g., dividends) is much older and constitutes an important element of the German institutional infrastructure.

Ever since the $19^{\text {th }}$ century, the connection between the accounting rules and distributions to shareholders has heavily influenced the nature of German accounting numbers. It was argued that if the profits of a company with limited liability are to be available for distribution, then German GAAP have to be interpreted in the light of precisely this purpose (the so-called teleological approach to law). This interpretation implies that the accounting rules must ensure payments to the owners but at the same time must also restrict payouts to the residual claimants. Payout determination ('Ausschüttungsbemessung') is therefore viewed as the primary purpose of the German individual accounts. 
As a consequence of this primary purpose, German accounting regulation severely restricts the realization of revenues. For instance, benefits resulting from long-term construction type contracts can be realized only after final inspection and approval of the client — or, in other words, revenues can be realized only if it is as sure as possible that there is no significant remaining risk to the transaction. Also, holding gains from changes in the market value of securities must not be recognized; these gains only show up in the income statement when the securities are actually sold. On the other hand, losses — as a result of the predominant legal principle of prudence - have to be recognized as soon as they arise.

Courts have developed a full scale of jurisprudence for accounting, which very often interprets accounting matters in the light of the underlying legal structure (e.g., using the specific contractual structure to determine the relevant economic benefits and risks). This approach leads to an emphasis on the reliability and the verifiability of accounting numbers. It manifests itself also in a very strict asset-liability approach to the balance sheet: Tangible things as well as legal rights are normally considered to be assets; things that only have a certain economic use are subject to additional recognition criteria. Intangible fixed assets that are self-generated by the company must not be recognized; if they are not self-generated they can be recognized if and only if they stem from reciprocal contracts with a third (independent) party. Deferred charges - which have been characterized as a 'dumping ground for a number of small items' (Kieso and Weygandt 1995: 590) in the United States - must not be included in the balance sheet because they lack the quality of an asset.

Similarly, accounting for liabilities and contingencies under German GAAP can generally be characterized as being more prudent than under US GAAP or IAS due to 
the legal concept that profits are available for distributions. ${ }^{9}$ However, the prudence principle does not imply that accounting for liabilities and contingencies is completely left to management's discretion. It must be kept in mind that accounting is also subject to court rulings in prior cases, which narrows management's room for accounting choices. The application of the principle of prudence is therefore limited from both directions.

German GAAP also govern the determination of income taxes (principle of the authoritativeness of accounting for tax purposes). Income determination for tax purposes as laid down in the Federal Income Taxation Act specifically refers to commercial law (i.e., the HGB). Systematically, however, the reason for this principle was always grounded in the idea that it would be unjust if the treasury demanded tax payments from corporations on a basis larger than that available for distributions to shareholders. Likewise, there would be no reason why taxes to the treasury should be derived from a smaller basis. Thus, it was postulated that, legally, the purposes of accounting for distributions and tax accounting are identical (Döllerer 1971: 1334). However, this conclusion is not equally valid for the consolidated accounts. Distributions and taxes are legally not tied to the consolidated accounts, which have exclusively informational purposes. ${ }^{10}$

In summary, recognition and measurement of assets and liabilities according to German GAAP is characterized by (1) the legal concept of distributable profits, (2) the principle of prudence, (3) the emphasis on objectification ('Objektivierung')which often means a focus on the nature of contracts and things-, as a

\footnotetext{
${ }^{9}$ Note however, that the $4^{\text {th }}$ European Directive also says that 'the principle of prudence has to be regarded under all circumstances' (Article 31).

${ }^{10}$ Of course, legally, the individual accounts have a very important informational function, too.
} 
counterbalance to this predominant civil law, (4) a substance-over-form approach and, finally, (5) a systematic and principles-based approach to accounting. Although the economic consequences of different modes of standard setting still need to be studied in greater detail, one should not underestimate the advantages of a legalistic concept, which lie in a systematic and principles-based approach and the resulting uniformity of terms across different fields of law.

\section{Information systems available to outside investors}

The fundamentals of German accounting and disclosure requirements are grounded in the regulations of the German Commercial Code and are equally binding for all legal types of firms (for details see Ballwieser 2001). The statutes oblige firms to keep books (HGB: $\S 238$ ), to draw up an inventory at the end of each financial year (HGB: $\S 240$ ), and to annually prepare a balance sheet and a profit and loss account (HGB: $\S 242$ ). Recognition and measurement of all elements of financial statements (assets, liabilities, revenues and expenses) have to be in accordance with German GAAP (HGB: $§ 243$ ). As indicated, the statutes and legal rules concerning recognition and measurement are supplemented by the exhaustive case law developed by the courts (predominantly tax courts), commentaries and the relevant literature of academic scholars (Moxter 2003: 9ff).

In addition to these general requirements, all firms organized as corporations have to add notes to the financial statements and, with the exception of small corporations, must prepare a management report. ${ }^{11}$ The annual report comprises the balance sheet, the income statement and accompanying notes (HGB: § 264). They constitute a

\footnotetext{
${ }^{11}$ This also applies to companies in other legal forms that are subject to the Public Disclosure Act because of their economic importance ('Publizitätsgesetz').
} 
composite whole. The annual report has to give a true and fair view of the corporation's financial position and results of operations. If the application of the relevant accounting and disclosure rules is not sufficient to give a true and fair view, additional information must be given (HGB: §264). For corporations, specific valuation rules, which are more investor-oriented than for those for non-corporations, apply (e.g. duty to reverse asset impairments if their reasons cease to exist, HGB: $\S 280$ ). The legal rules also prescribe very detailed und uniform formal requirements (layouts) for the presentation of the balance sheet and the profit and loss account (HGB: $\S \S 266,275)$. The contents of the notes to the financial statements include details on the applied accounting policies, the individual positions of the balance sheet and the profit and loss account as well as on specific valuation methods (HGB: $\S 284)$. The disclosure rules further require information about specific items that are not in the financial statements, for instance, the total amount of financial commitments that are not included in the balance sheet, a detailed breakdown of revenues, the number of employees, and the total sum of management's compensation (HGB: §285). However, the corporation must not disclose facts that endanger national welfare and they may omit some of the required information if they are to the disadvantage of the corporation (HGB: $\S 286$ ). The management report must include (1) a fair report on the corporation's prospects with particular emphasis on future risks (GAS 5), (2) a statement on material events that happened after the balance sheet date, and (3) a report on research and development activities of the corporation (HGB: $\S 289)$. In contrast to the financial statements, the management report presents results and prospects from management's viewpoint, and thereby complements the annual report. $^{12}$

\footnotetext{
${ }^{12}$ It therefore can be compared with SEC's MD\&A disclosure.
} 
In addition to the annual report for the individual accounts, a corporation that controls subsidiary undertakings has to draw up consolidated (or group) accounts and to provide a consolidated annual report (HGB: $§ 290) .{ }^{13}$ The consolidated annual report comprises the consolidated balance sheet, the consolidated profit and loss account, and accompanying notes (HGB: § 297; for details see Ordelheide 2001). Legal rules, commentaries, literature of academic scholars and GAS detail consolidation techniques as well as accounting and disclosure requirements. The consolidated report is again supplemented by a management report (HGB: $\S 315$ ). As mentioned before, the group accounts are neither the basis of dividends nor tax payments; they serve purely informational purposes. However, recent amendments to the German Corporation Code ('Aktiengesetz'-AktG-) could give grounds for legal action against the management and the supervisory board on the basis of the consolidated annual report (AktG: $\S \S 170,171)$.

As an alternative to German GAAP, corporations with publicly traded securities can prepare their consolidated annual reports in conformity with either IAS or US GAAP (HGB: $\S 292 a)$. The resulting choice between three different accounting and disclosure regimes for the consolidated annual report, which remains until 2004, is quite unique and may prove as an interesting field for future research in the field of regulatory competition of accounting regimes (e.g. Leuz and Verrecchia, 2000; Leuz, 2003). The appendix to this chapter provides descriptive statistics on the application of the three accounting regimes in Germany.

\footnotetext{
13 This requirement also applies to companies in other legal forms if they are subject to the Public Disclosure Act because of their economic importance.
} 
Although the fundamental accounting and disclosure requirements are set forth in corporate law, there are supplementary information requirements for listed companies, which are laid down in the German securities laws. The most important requirements can be organized along the following lines:

(1) Recent amendments to the basic consolidated financial statements following the 1998 Corporate Control and Transparency Act: Listed companies have to present a statement of cash flows (GAS 2), segment reporting (GAS 3), and a statement of changes in equity (GAS 7). These statements form a separate part of the notes (HGB: $\S 297)$.

(2) Prospectus: Corporations issuing shares have to file prospectuses. In these ‘information tableaux' (Hommelhoff 2000: 756), financial statements (both annual accounts and group accounts are required) serve only as one of the key pieces of information that shall enable investors to properly evaluate business and prospects of the issuing corporation (Stock Exchange Act ('Börsengesetz'—BörsG-): § 30).

(3) Interim financial reporting: Listed companies are also generally required to publish at least one set of interim financial statements during the financial year. The interim financial statements shall give a true and fair view of the firm's financial position and the results of operations (BörsG: $\S 40$ ).

(4) Ad-hoc disclosure: German securities law requires issuers to disclose any material new fact that is capable of considerably influencing its share prices (WpHG: $\S 15)$.

(5) Disclosure requirement in specific equity market segments: Under public law, a listing in the 'Segment Prime Standard' of the Frankfurt Stock Exchange requires, as an example, quarterly reports, application of international standards, and ad-hoc disclosure in English language (Frankfurt Stock Exchange Regulation 
('Börsenordnung'): $\S \S 62,63,66) .{ }^{14}$ In addition, the stock exchange may prescribe alternative or supplementary disclosure requirements on the basis of private law. To be listed at the former New Market, for instance, the Frankfurt Stock Exchange required companies to prepare their financial statements in accordance with either US GAAP or IAS, and to publish quarterly reports. ${ }^{15}$

In summary, the information system available to outside investors has two characteristics: First, at the company law level, the dissemination of information is highly harmonized and integrated for different legal types of economic firms. It gives investors a standardized set of financial information which is not dependent on, for instance, state regulation of corporation law. Second, at the level of securities regulation, diverse reporting requirements prevail. They certainly have important interdependences, but they are not fully integrated. ${ }^{16}$ We see this as a possible shortcoming of the information system available to outside investors in Germany. Moreover, the sanctions and liabilities are not dependent on any general type of 'misleading statements' as they are in the USA by means of rule 10b-5 and rule 14a-9, which in principle even extends to oral statements by management.

\section{Private information systems}

According to our hypotheses, the key financing parties in an insider system are less reliant on public information of the type discussed so far because they have access to private information channels. In the following, we examine how German corporate governance allocates informational rights to the key contracting and financing parties

\footnotetext{
${ }^{14}$ See Chapter 10 of this book for details on the various segments of the German stock market.

${ }^{15}$ See section 7.1 and 7.2.2 New Market Regulation.

${ }^{16}$ The public disclosure system in German securities regulation (but not company law) somewhat resembles the situation in the U.S. before the reforms that led to the 'integrated disclosure system' (see Loss and Seligman 1999: 606-627; Wüstemann 2002a: 132 ff.).
} 
permitting and improving their control of management. These informational rights create several private information systems, which all reduce informational asymmetries between ownership and control. They constitute individual and separate ‘information regimes’ (Hommelhoff 2000: 749).

First, there exists a sophisticated system that confers informational rights on individual shareholders and does not depend on a controlling stake in the company (e.g. HGB: $\S 325$; AktG: $\S 131$ ). The group of shareholders encompasses —as a result of the Treaty of the European Union and rulings of the European High Court—not only current shareholders but also potential shareholders. However, there are certain informational rights that assume a factual position as shareholder and hence can not be viewed as part of the public information system. For instance, informational rights at the shareholders' general meeting can only be exercised if one is already a shareholder of the company. In addition to the individual rights of all shareholders, there are informational rights, which are only attached to those shareholders who are members of the supervisory board. A membership in the supervisory board gives broad access to virtually any value-relevant information of the company. The legal rules explicitly oblige management to furnish this information. Its reporting duties cover, for instance, financing and investment decisions, human resource management, the corporation's profitability and questions of corporate strategy (AktG: $\S 90)$.

As another important source of finance, creditors also have important informational rights: principal creditors may — and very often do indeed — claim a seat in the supervisory board. Creditors are not only entitled but required by German banking law to obtain detailed non-public information about a company's prospects for any credit exceeding 250,000 Euro (KWG: $\S 18$; Chapter 7 of this book). Finally, the German Hausbank system with its relationship lending ensures detailed cash-flow 
information about all financial transactions handled by the Hausbank, thereby giving banks a broad database of historical information, e.g., a company's paying habits, to their default risks.

A very important but less known private information channel in the system of German corporate governance is the audit report (Ballwieser 2001; Ordelheide and Pfaff 1994; Schmidt 1998; Baetge and Thiele 1998). Audit reports in German corporation law have to be distinguished from an audit opinion ('Bestätigungsvermerk'). In the audit opinion the auditor briefly expresses whether he regards the company's accounting as conforming to German GAAP, often in a boilerplate fashion. Audit opinions are published in the annual report and are a part of the public disclosure system. In contrast, the audit report has to be submitted only to the managing board of directors and the supervisory board. Recent legislation has made clear that all members of the supervisory board have to be given copies of the audit report. In the past, practice of some firms has been to exclude some board members, especially labor representatives from the report (Schmidt 1998: 750). It is an interesting feature of Germany's system of corporate governance that the audit report is not available for common shareholders, not even at their general meeting. In the first part of the audit report, the auditor has to stress the company's future prospects and especially those factors which threaten its survival. In its main parts, the auditor has to describe and analyze all items on the balance sheet that have a material influence on the firm's financial position. Moreover, the auditor has to evaluate the consequences of all significant accounting choices. This means, for example, explaining the effects of sale-and-lease-back transactions. The auditor also has to pass judgment on accounting choices within the management's discretion (e.g. overly optimistic but legally justifiable estimations of uncertain liabilities). An audit report of 
a publicly traded DAX 30 company has the size of several hundred pages. Wüstemann (2001) shows in his analysis of the relevant legal rules that an audit report leads to a much broader insight into a firm's financial position and results than publicly available annual reports. For instance, the requirement to analyze the consequences of accounting choices on the firm's financial position exceeds public disclosure requirements. In the notes to the public financial statements, such an analysis is not generally required, even if it was of legitimate interest to outside investors. Wüstemann (2002b) argues that recent legislation has even strengthened these tendencies. The legal evidence indicates a relatively high stability of private information channels in the traditional German corporate governance and suggests rather constant informational asymmetries within the group of shareholders. These recent changes were expressly meant as a reinforcement of the (private) information flows within the firm and to the relevant monitoring parties (Reform Act ('TransPuG') 2000: 18). They were rounded off by measures to increase information flows to outside investors as well (e. g. the requirement to disclose a statement of retained earnings for certain public corporations).

Recent decisions of Germany's Supreme Court may serve as the last piece of institutional evidence on the relative importance of the channels that give insiders in the German financial system privileged information and control rights. ${ }^{17}$ In the underlying case, a legal norm was challenged which gives management the right not to answer any questions concerning the difference between the book value and the fair value of the assets at the shareholders' general meeting (AktG: $§ 131$ ). Plaintiffs argued that without this information a control of management would not be effective

\footnotetext{
${ }^{17}$ See Decisions of the German Supreme Court from September 20, 1999 - 1 BvR 636/95 and 1 BvR $168 / 93$.
} 
since hidden reserves would distort a fair presentation of the company's financial position, thereby enabling management to draw on the reserves unnoticed and to cover up the firm's true financial position. In its decisions the court pointed out that the legal guarantee of property rights includes the right to obtain information over matters of the company in which one is a shareholder. The right to obtain information is hence a material component of shareholder rights. According to the court ruling, however, management's right to refuse information ( $\S 131 \mathrm{AktG})$ is the proper restraint of the former: Hidden reserves are viewed as a means to protect against possible risks of insolvency and to secure the corporation against general risks for which there would be no protection otherwise. That is, in the court's view, hidden reserves can be in the interest of the company ('Gesellschaftsinteresse'). The challenged disclosure of hidden reserves would complicate the necessary measures of precaution considerably. The court also pointed out that the existence of hidden reserves could be in the interest of controlling shareholders, for whom entrepreneurial aspects are more important than distributions. Thus, the court ruling explicitly acknowledges the existence of divergent interests of majority and minority shareholders, but it also identifies information and control rights that are only available to majority shareholders, thereby granting them legitimate ways of exerting insider control. This is consistent with our main hypothesis that institutional arrangements are geared towards the main contracting parties.

In summary, our institutional analysis suggests that the key contracting parties in Germany are reasonably well informed once we consider both private and public sources of information. In fact, it seems plausible that they are at least as well informed as investors in an outsider system with extensive public disclosure 
requirements. ${ }^{18}$ It has to be emphasized that the supply with information to controlling insiders and the supervisory board does not have an informal character but follows along legal rules, which ensures that the information flows are-as legally protected interests - enforceable. However, the existence of private information regimes also implies an informational disadvantage of outside investors.

\section{Enforcement of accounting rules}

Enforcement of accounting and disclosure rules can be achieved either via corporate governance or market regulation. In Germany, enforcement is basically driven by corporate governance. We identify and discuss three main enforcement mechanisms, which all have been strengthened recently (2002 Reform Act). First, management itself is obliged by law to ensure proper application of accounting standards. The management also has to establish a monitoring system which enables it to detect developments that might endanger the economic survival of the corporation. Second, the supervisory board has to examine the financial statements, supported therein by the audit report and the auditor, either during meetings of the audit committee or in the general meeting of the supervisory board. Finally, it is the purpose of the statutory audit to guarantee that firm's financial statements give a true and fair view of the company's financial position and results. In order to strengthen the auditor's independence, the 1998 Corporate Control and Transparency Act introduced among other rules a rotation of the responsible auditor (but not the audit firm) after 6 years. The 1998 Corporate Control and Transparency Act also requires that the supervisory board hires the audit firm. Before the reform, the management

\footnotetext{
${ }^{18}$ In contrast, securities regulation in the U.S. stresses the importance of equally distributed disclosure (e.g. Regulation FD).
} 
board hired the auditors, which raised questions concerning the auditors' independence. The enforcement of either IAS or US GAAP lies with the auditors, whose legal liability has considerably increased since an amendment of the German Commercial Code (HGB: $\S 323$ ) enacted by the 1998 Corporate Control and Transparency Act. In addition, auditors and directors could face criminal prosecution for misleading or fraudulent financial statements (HGB: $\S \S 331,332$ ). It is also possible to sue for damages in civil courts, but only after a conviction in criminal proceedings.

US-style litigation or SEC-like monitoring does not exist. But recent legislation has at least established certain elements of a market oriented enforcement of accounting standards. For the first time, shareholders in Germany can sue the company on the grounds of misleading statements resulting in losses from irregular share prices (Fourth Financial Market Reform Act 2002 ('Viertes Finanzmarktförderungsgesetz'). In addition, it has been proposed to establish a private enforcement panel, following the British example of the Financial Reporting Review Panel (FRRP). This panel will investigate any complaints from private persons about violations of the accounting standards that materially affect a company's financial position. A possible establishment of a state agency like the SEC was discussed but rejected. Some enforcement is exercised by the monitoring activities of the State Bars of Certified Public Accountants ('Wirtschaftsprüferkammern'), which regularly review published annual reports and which have established a system of peer reviews following the U.S. example (prior to the recent changes induced by the SarbanesOxley Act). Limited enforcement could also result from the registration department of the stock exchanges, e.g., the Frankfurt Stock Exchange. Last, but not least, indirect enforcement of accounting rules results from the activities of tax authorities. Since the 
individual accounts are authoritative for tax purposes, enforcement actions by the tax authorities regarding the tax accounts have repercussions for the underlying individual accounts (e.g. questions of recognition of assets, liabilities, revenues and expenses). Interestingly, this enforcement mechanism is weakened by recent trends towards international accepted accounting standards for the consolidated accounts.

\section{EMPIRICAL EVIDENCE}

In this section, we provide a brief survey of the empirical accounting literature using German data (for earlier reviews Coenenberg et al. 1984; Möller and Keller 1999). We review empirical studies on (1) financial statements, (2) other financial disclosures to the capital markets, (3) the role of accounting in contracting and corporate governance (4) earnings management and enforcement. We organize our review along six hypotheses, which are based on the preceding institutional analysis as well as extant accounting and finance research.

Hypothesis 1 (Price-Earnings-Relations): The institutional analysis suggests that the key contracting and financing parties in Germany are reasonably well informed. Direct evidence supporting this prediction is likely to be limited since the information is communicated mainly via private channels. However, share prices can provide indirect evidence. If insiders can trade based on privately communicated information, prices should reflect this information in a timely fashion and well before it is incorporated in the accounting numbers and publicly disclosed. ${ }^{19}$ Thus, private information transmission in conjunction with insider trading reduces the contemporaneous association of accounting numbers with stock returns (i.e. their

\footnotetext{
${ }^{19}$ The information is eventually reflected in earnings, for instance, when the cash flows are realized.
} 
value relevance) and increases the interval by which prices lead accounting numbers. $^{20}$

Several empirical studies suggest that, despite voluntarily adopted restrictions, insider trading was fairly widespread in Germany, at least until 1994, when insider trading became illegal (e.g. Seeger 1998). But even thereafter, reporting of insider trades was not required until 2002. The lack of reporting requirements and recent anecdotal evidence question whether insider trading was effectively curbed. We therefore expect that the contemporaneous association of earnings and stock returns is lower and that prices lead earnings over longer intervals in Germany than in countries with strictly enforced insider trading provisions.

There are several studies examining the value relevance of earnings and shareholders' equity of German firms. Joos and Lang (1994) find that the value relevance of earnings and book value of equity are comparable in Germany and the UK using price and 18-month return regressions. Harris et al. (1994) compare German and US accounting numbers and report that the value relevance of earnings is comparable, but that shareholders' equity in Germany is significantly less associated with share price than in the US. In contrast, the results of Alford et al. (1993) suggest that German earnings are less value relevant than US (or UK) earnings because (a) they exhibit a significantly lower association with 15-month stock returns and (b) they capture a smaller proportion of the total information impounded in share price using a hedge portfolio approach. Ali and Hwang (2000) report that the value relevance is lower in 'bank-oriented' financial systems, such as the German, than in 'marketoriented' financial systems, such as the UK or the US, using several measures of

\footnotetext{
${ }^{20}$ See Kothari and Sloan (1992) for the idea of prices leading earnings. Jacobson and Aaker (1993) make a similar argument for Japan and present supporting evidence.
} 
value relevance. Finally, Ball et al. (2000) analyze the timeliness of earnings across countries using reverse regressions (i.e. earnings on returns). They show that (a) earnings are significantly more timely in common-law countries, such as the US, than in code-law countries, such as Germany, and (b) that this finding is primarily driven by the timely recognition of economic losses in earnings, which is suggested to facilitate outsider monitoring.

Studies explicitly comparing the lead-lag structure of stock returns and earnings for Germany and Anglo-American countries do not exist. However, Ali and Hwang (2000) document that the fraction of earnings information incorporated in leadingperiod (as opposed to contemporaneous) returns is greater for bank-oriented countries. This finding is consistent with German returns leading earnings over a longer interval than in the UK or the US.

Overall, the evidence is consistent with the hypothesis that German accounting numbers are less value relevant and less timely in part because prices reflect information privately communicated to key parties. However, the value relevance of earnings and the lead-lag structure with prices are also affected by other factors (e.g. poor accounting quality and earnings management), making it difficult to attribute the results solely to the transmission of information via private channels. ${ }^{21}$

Hypothesis 2 (Announcement Returns): A further implication of private communication (and insider trading) is that the information content of accounting numbers at the time of their public announcement is low. That is, the stock market reaction to the public announcement is weak because insiders already possess the

\footnotetext{
${ }^{21}$ Comparative value relevance studies often ascribe their findings to differences in accounting quality. However, differences in information channels are an equally plausible explanation.
} 
information contained in the accounting numbers and have traded on it. Based on this logic, we expect the information content of financial statements to be lower in Germany than, for example, in the US.

There are several event studies examining the information content of various German accounting reports (e.g. Coenenberg and Möller 1979; Keller and Möller 1993). They generally conclude that unexpected realizations of accounting numbers lead to significant stock market reactions around the event date. However, it is difficult to compare these reactions and the implied information content to findings in other countries. The stock market reaction at the announcement is not only a function of how much private information is already impounded in prices. Other factors are likely to differ across countries and may even pull in opposite directions. For instance, poor quality of the announced information and high quality interim disclosures both reduce the information content of announcements. Thus, it is again difficult to attribute differences in information content solely to the channels of information transmission.

Extant studies nevertheless provide several indications that the information content of German accounting numbers at the time of their public announcement is relatively low, consistent with our hypothesis. First, early German event studies do not use the press release date, but define preceding ones, such as the supervisory board meeting or the completion of the audit. These event dates are explicitly chosen to address information leakage and insider trading (e.g. Keller and Möller 1992; Seeger 1998). Recent changes in the securities laws (notably WpHG: $\S 15$ ) that stipulate ad-hoc disclosure of price-relevant information are likely to mitigate these problems (Nowak 2001a). Second, even after these changes in 1995, event studies continue to exhibit relatively low significance levels. Only a small fraction of the market reactions 
(frequently less than $10 \%$ of the sample) are individually significant (Nowak 2001a). These findings are likely to reflect the difficulty of measuring the information content of news announcements in an environment where the key financing parties have private access to information. $^{22}$

Hypothesis 3 (Transparency): Given that the key contracting parties are less reliant on public information, the level and the quality of financial disclosures of German firms are likely to be low compared to other countries where arm's-length investors play a larger role.

Consistent with this hypothesis, several international comparisons document that the level of financial disclosure is low in Germany compared to the UK or the US. For instance, the disclosure index developed by Saudagaran and Biddle (1992) ranks Germany only seventh out of eight countries, whereas the US is first and the UK third. Similarly, the CIFAR disclosure index reported in La Porta et al. (1998) assigns only rank 25 (out of 41) to Germany, whereas the UK and the US take the places 4 and 11, respectively. These studies generally rely on indices of disclosure practice and hence measure both mandatory and voluntary disclosures. Cooke and Wallace (1990) focus specifically on disclosure regulation and find that Germany has fewer mandated disclosures than the UK or the US. More recently, La Porta et al. (2002) conduct a comprehensive survey of disclosure requirements prior to security offerings in 49 countries. Germany ranks only in $39^{\text {th }}$ place and exhibits lower disclosure requirements than most developed countries. All these findings are consistent with the view that, in Germany, public disclosure plays a minor role in informing the key

\footnotetext{
${ }^{22}$ Another problem is the correct specification of the market's expectations. Even the more recent convention to use analysts' forecasts as a proxy is unlikely to solve the problem as analysts' expectations may not reflect the marginal investor's expectation in insider economies.
} 
financing and contracting parties. Interestingly, this view seems to be shared by both firms and regulators.

However, there are also studies suggesting that disclosure levels may not be low for every information type. For instance, Frost and Ramin (1997) report that German firms provide more earnings and sales forecasts than UK or US firms. ${ }^{23}$ On one hand, this finding is consistent with the low risk of shareholder litigation in Germany. But on the other hand, such disclosures are less likely to be important in the German environment. Consistent with the latter view, Meek and Gray (1989) and Baetge et al. (1997) find that forward-looking disclosures in German annual reports are particularly poor. More research is necessary to resolve this apparent contradiction.

Hypothesis 4 (Voluntary Disclosures): Although the 'typical' German firm is characterized by concentrated ownership and strong reliance on private financing, there are German firms with less traditional capital and ownership structures. As these firms rely more on arm's length financing, they have stronger incentives to communicate information publicly. Economic theory suggests that these firms voluntarily provide additional information and exceed mandatory disclosures. They could also adopt more informative accounting standards or cross list in the UK or the US, thereby committing to higher disclosure standards.

Studies using firm-level data reveal considerable cross-sectional variation in the disclosure practice across German firms (e.g. Coenenberg et al. 1984, for a survey of earlier studies). The results, which are generally consistent with disclosure theory and evidence in other countries, suggest that external financing needs, dispersed

\footnotetext{
${ }^{23}$ Along the same lines, Meek and Gray (1989) compare voluntary disclosures of European firms listed at the London Stock Exchange and find that German firms are particularly forthcoming in their employee disclosures, social and environmental reporting, but not in their financial disclosures.
} 
ownership, and foreign listings are among the key determinants of voluntary disclosures in Germany. For instance, Leuz (2003a) presents evidence that firms trade off capital-market benefits (e.g. external financing) and proprietary costs in deciding whether to disclose segment information. Leuz (2000) analyzes the adoption pattern of voluntary cash flow statements that are in line with international practice. He finds that German firms facing pressures in the international capital markets are among the first to voluntarily disclose such statements, followed by firms that are likely to have relatively high benefits in the domestic capital markets.

The latter study also suggests a trend towards improved disclosure. Disclosure index studies conducted at regular intervals confirm that German disclosure practice is steadily improving (Baetge et al. 1997). In particular, the number of firms presenting financial statements in accordance with international standards, such as IAS and US GAAP, is rapidly increasing (see also our Appendix). Leuz and Verrecchia (2000) document that German firms voluntarily adopting financial statements in accordance with international standards, such as IAS or US GAAP, garner substantial capital-market benefits. Although these trends are consistent with Germany's recent movements towards a more capital-market oriented financial system, more research is necessary to establish whether these developments are in fact fundamental changes in firms' disclosure policies or whether the documented economic benefits are based on perhaps unwarranted expectations. In this regard, the now closed New Market at the Frankfurt Stock Exchange provides an interesting example (Leuz 2003b).

Hypothesis 5 (Dividend Restrictions): The institutional analysis in Section 3 emphasizes the important role of German accounting numbers in determining payouts 
(e.g. dividends, taxes). In particular, the fact that accounting rules are geared towards restricting dividends to shareholders is likely to be reflected in German debt contracts.

There are few studies that systematically study the use of earnings and other accounting numbers in contracts for German firms. One reason is that there is no disclosure requirement for bonus or debt contracts, which is not surprising given the nature of the German institutional framework. ${ }^{24}$ However, there are several studies that provide indirect evidence supporting hypothesis 5. First, Harris et al. (1994) find that the dividend payout level is significantly higher in Germany than in the US. This finding highlights the importance of dividends and payout determination in Germany. Second, Ball et al. (2000) report that, in Germany, dividends are timelier than earnings, i.e., dividends incorporate a larger proportion of economic income as measured by the stock return. This finding again emphasizes the special role of dividends in Germany.

More direct evidence on the role of accounting in German debt contracting provides a study by Leuz et al. (1998). They compare legal and contractual dividend restrictions in the UK, the US and Germany and find that contractual restrictions are very rare in Germany and used only in special circumstances. This result is in contrast to the ubiquity of dividends constraints in UK and US debt agreements. However, German corporate law imposes detailed payout restrictions and the accounting rules are geared towards the problem of restricting dividends to shareholders. Survey evidence and the fact that these legal restrictions are similar to the contractual constraints in the UK and the US suggest that the existence of relatively strong legal

\footnotetext{
${ }^{24}$ Schwalbach and Graßhoff (1997) report based on estimates by Kienbaum Consulting that roughly $90 \%$ of Germany's top executives receive (variable) incentive packages amounting to about $25-40 \%$ of the total compensation. But they do not report how incentive compensation is determined.
} 
restrictions is responsible for the lack of contractual dividend restrictions in Germany. $^{25}$

Finally, McLeay et al. (2000) present indirect evidence of a different sort. They analyze constituent lobbying and its impact on the development of financial reporting regulation in Germany. Studying commentaries on draft accounting legislation, they identify three primary constituencies: (1) industry and banks, (2) auditors and (3) academic experts. Of the three groups, the first exerts the strongest influence-in particular with respect to disclosure issues. Noteworthy and consistent with the (contracting) role of accounting in the German economy is the absence of financial analysts and arm's length investors in the political process.

Hypothesis 6 (Earnings Management and Enforcement): Based on the role of reported earnings in the German institutional setting, we conjecture that earnings management is more prevalent in Germany than in outsider economies. First, as the key contracting parties rely less on reported earnings to make investment decisions or monitor firms, there is less demand for earnings that accurately reflect a firm's operating performance (Ball et al. 2000; Ball 2001). Second, insiders enjoy higher private control benefits in the German setting than in outsider economies and hence have a greater need to conceal or obfuscate firm performance to reduce outsider interference (Leuz et al. 2003).

There is ample anecdotal evidence of earnings management. German firms are frequently criticized for their 'hidden reserves' used to manipulate earnings (Coenenberg et al. 1984; Harris et al. 1994: 188). But there are also several empirical

\footnotetext{
${ }^{25}$ The institutional comparison of legal payout restrictions in the US and Germany by Wüstemann (1996) further supports this view. He concludes that the US restrictions in state corporation law are relatively weak, which essentially leaves the problem to debt contracting.
} 
studies providing evidence consistent with our hypothesis. For instance, Keller and Möller (1992) compare financial reports of industrials and banks in terms of their information content. They document that the reports' information content is considerably lower for banks than industrials. As German banks have more discretion in valuing their assets (e.g. loan loss reserves) than industrials, they view their finding as evidence of substantial earnings management, but it could also reflect the opaque nature of banks. The findings in Ball et al. (2000) on the properties of earnings are consistent with the hypothesis that German firms engage in more earnings management than firms in the US or the UK. Analyzing the degree of flexibility embedded in the accounting standards, d'Arcy (2000) shows that the codified rules grant managers more accounting choices than UK or US standards, which could give rise to more earnings management. However, as explained in Section 3, German GAAP are not determined by the codified rules alone, making a comparison difficult.

More directly addressing the hypothesis, Leuz et al. (2003) examine the pervasiveness of earnings management across 31 countries. Their evidence suggests that the level of earnings management and income smoothing is higher in Germany than in outsider economies like the UK or the US. The study also documents that earnings management is negatively associated with outside investor protection and positively associated with private control benefits. Thus, it should not come as a surprise that Germany exhibits relatively high levels of earnings management.

The reliance on insider control and the relatively low demand for public information that accurately reflect firms' operating performance is also reflected in the enforcement of accounting rules. Anecdotal evidence suggests that the level of enforcement in the area of consolidated financial accounting is rather low (e.g. Ordelheide 1998). Recent studies by Glaum and Street (2003) and Gebhardt and 
Heilmann (2003) show that there is considerable cross-sectional variation in firms' compliance with German and international accounting standards, which is also consistent with low enforcement. Unfortunately, an empirical study that explicitly compares the level of accounting enforcement across countries does not exist.

In summary, we find that the extant literature broadly supports our hypotheses. In many areas, however, more research is necessary to explicitly address these hypotheses and to improve our understanding of the links between accounting, disclosure and the financial system in Germany (and elsewhere).

\section{CONCLUSION}

This chapter analyzes the role of financial accounting in the German financial system. We begin our analysis by noting that the widespread characterization of German accounting as rather 'uninformative' stems from an implicit or explicit comparison with accounting systems in outsider economies like the US and the UK. We therefore adopt a broader perspective and include public disclosure and private information channels in our institutional analysis of the German accounting system.

Confining the comparison to financial statements and disclosure, outside investors relying primarily on public information seem not as well informed in the German system as they are in the Anglo-American economies. However, the German accounting system exhibits several arrangements that privately communicate information to insiders, notably the supervisory board. Due to these features, the key financing and contracting parties seem reasonably well informed. Thus, the informativeness of the German accounting system depends on which elements of the system and which parties are included in the analysis. 
Our survey of extant empirical accounting research generally supports these arguments. The evidence is consistent with the notion that the German accounting system is not geared as much towards arm's length investors as the US or the UK system. It suggests that the level of public disclosure is lower in Germany and that financial statements of German firms are generally less informative than those of UK or US firms. Moreover, stock price reactions to and associations with accounting numbers are consistent with the notion that a substantial amount of information is communicated via private channels. However, there is little research that directly addresses the informedness of arm's length investors in Germany and even less direct evidence on how well insiders are informed. Our conclusions should therefore be viewed as hypotheses and as motivation for future research, rather than answers to the questions posed in the introduction.

Areas for future research also arise from recent institutional reforms in Germany and Europe such as the adoption of IAS. We argue that these changes have not yet fundamentally altered the German accounting system and its reliance on private information channels and insider governance. Complementarities among the elements of the institutional framework make it unlikely that reforms take hold unless several other elements of the system are changed simultaneously (e.g. Ball 2001). Although the process towards an outsider system seems to have been set in motion and several elements of the German institutional framework have been reformed, there are still many areas, which are crucial to an outsider system but are largely unchanged (e.g., enforcement of accounting rules and shareholder litigation).

Before these reforms take place, we are skeptical that the recent changes have fundamentally and lastingly altered the German accounting system and its informational properties. Frankfurt's-now closed-New Market provides a case in 
point. The experience with this stock market segment illustrates the importance of enforcement and that changing the accounting standards is unlikely to be sufficient to ensure high-quality information to outside investors. In fact, recent studies provide evidence that accounting quality is largely determined by firms' reporting incentives, and not the accounting standards per se (e.g. Ball and Shivakumar 2002; Ball et al. 2003; Leuz 2003b; Leuz et al. 2003). The idea is that accounting standards necessarily leave discretion and that this discretion is used (or abused) depending on controlling insiders' incentives, which in turn are shaped by corporate governance and institutional factors. These findings suggest that if accounting and disclosure practice is to be improved, the emphasis should not be on reforming accounting standards, but on improving firms' reporting incentives by changing the institutional framework and, in particular, corporate governance. Advancing our understanding of these links is an important area for future research. 


\section{References}

Alford, A., J. Jones, R. LefTwiCh, AND M. ZMiJewsKi. 1993. 'The Relative Informativeness of Accounting Disclosures in Different Countries.' Journal of Accounting Research 31. Supplement: 183-223.

Ali, A., AND L. Hwang. 2000. 'Country-Specific Factors Related to Financial Reporting and the Value Relevance of Accounting Data.' Journal of Accounting Research 38: 1-23.

Allen, F., AND D. Gale. 2000. Comparing Financial Systems. Cambridge: MIT Press.

BAetge, J., AND S. Thiele. 1998. 'Disclosure and Auditing as Affecting Corporate Governance.', In Comparative Corporate Governance, eds. K. J. Hopt et al. Oxford: Oxford University Press: 719-741.

Baetge, J., K. Armeloh, And D. Schulze. 1997. 'Empirische Befunde über die Qualität der Geschäftsberichterstattung börsennotierter deutscher Kapitalgesellschaften.' Deutsches Steuerrecht 35: 212-219.

BALL, R. 2001. 'Infrastructure requirements in the area of accounting and disclosure policy' In Brookings-Wharton Papers on Financial Services, eds. R. Litan and R. Herring. Washington: Brookings Institution Press: 127-169.

BALL, R., S. KOTHARI, AND A. RoBIN. 2000. 'The effect of international institutional factors on properties of accounting earnings.' Journal of Accounting and Economics 29: $1-52$.

BALL, R., A. RoBIn, AND J. WU. 2003. 'Incentives versus Standards: Properties of Accounting Income in Four East Asian Countries, and Implications for Acceptance of IAS' Journal of Accounting and Economics. Forthcoming.

BALl, R., AND L. ShIVAKumar. 2002. 'Earnings Quality in U.K. Private Firms.' Working Paper. University of Chicago and London Business School.

BALLWIESER, W. 2001. 'Germany - Individual Accounts.' In Transnational Accounting, eds. D. Ordelheide and KPMG. 2nd edn. New York: Palgrave: 12171351.

BEISSE, H. 1994. ,Zum neuen Bild des Bilanzrechtssystems.' In Bilanzrecht und Kapitalmarkt: Festschrift zum 65. Geburtstag von Prof. Dr. Dr. h. c. Dr. h. Adolf Moxter, eds. W. Ballwieser et al. Düsseldorf: IDW-Verlag: 3-31.

BERGLÖF, E. 1997. 'A note on the typology of financial systems.' In Comparative corporate governance: Essays and materials, eds. K. J. Hopt and E. Wymeersch. Berlin et al.: Gruyter: 151-164.

COENENBERG, A., AND H. P. MöLlER. 1979. 'Entscheidungswirkungen von Jahresabschlußinformationen vor und nach der Aktienrechtsreform von 1965.' Betriebswirtschaftliche Forschung und Praxis 31: 438-454.

Coenenberg, A., H. P. Möller, And F. SCHMidT. 1984. 'Empirical research in financial accounting in Germany, Austria and Switzerland: A review.' In European contribution to accounting research-The achievements of the last decade, eds. A. Hopwood and H. Schreuder. Amsterdam: 61-81. 
COOKE, T., AND R. WALlaCE. 1990. 'Financial Disclosure Regulation and Its Environment: A Review and Further Analysis.' Journal of Accounting and Public Policy 9: 79-110.

D'ARCY, A. 2000. 'The Degree of Determination of National Accounting Systems An Empirical Investigation.' Schmalenbach Business Review 52: 45-67.

DöLlERER, G. 1971. 'Maßgeblichkeitsprinzip der Handelsbilanz in Gefahr.' BetriebsBerater 26: 1333-1335.

EulER, R. 1996. Das System der Grundsätze ordnungsmäßiger Bilanzierung. Stuttgart: Schäffer-Pöschel.

FISCHER T., S. BECKER, AND J. WENZEL. 2001. 'Wertorientierte Berichterstattung - Ein empirischer Vergleich der internetbasierten Geschäftsberichte von DAX 30- und Nemax 50-Unternehmen.' Kapitalmarktorientierte Rechnungslegung 2: 14-25.

FRANKS, J., AND C. MAYER. 1994. 'Corporate control: A comparison of insider and outsider systems.’ Working Paper. London Business School.

FRESL, K. D. 2000. Die Europäisierung des deutschen Bilanzrechts. Wiesbaden: Gabler.

Frost, C., AND K. RAMIN. 1997. 'Corporate Financial Disclosure: A Global Assessment.' In International Accounting and Finance Handbook. 2nd edn. Ed. F. Choi. New York: Wiley: Chapter 18.

Gebhardt, G., AND A. Heilmann. 2003. 'Compliance with German and International Accounting Standards in Germany: Evidence from Cash Flow Statements.' In Economics and Politics of Accounting, eds. A. Hopwood et al. Oxford: Oxford University Press. Forthcoming.

Glaum, M. 2001. 'Die Internationalisierung der deutschen Rechnungslegung.' Kapitalmarktorientierte Rechnungslegung 1: 124-134.

Glaum, M., AND D. StReEt. 2003. 'Compliance with the Disclosure Requirements of Germany's New Market: IAS versus US GAAP.' Journal of International Financial Management and Accounting. Forthcoming.

Hackethal, A., AND R. H. Schmidt. 2000. 'Finanzsystem und Komplementarität.' In Finanzmärkte im Umbruch, Beihefte zu Kredit und Kapital. Heft 15. Eds. H. Francke et al. Berlin: Duncker \& Humblot: 53-102.

HARRIS, T., M. LANG, AND H. MÖLLER. 1994. 'The value relevance of German accounting measures: An empirical analysis.' Journal of Accounting Research 32: 187-209.

HoMmelhoff, P. 2000. 'Anlegerinformationen im Aktien-, Bilanz- und Kapitalmarktrecht.' Zeitschrift für Unternehmens- und Gesellschaftsrecht 29: 748775 .

JACOBSON, R., AND D. AAKER. 1993. 'Myopic Management Behavior with Efficient, but Imperfect Financial Markets: A Comparison of Information Asymmetries in the US and Japan.' Journal of Accounting and Economics 22: 383-406.

Joos, P., AND M. LANG. 1994. 'The Effects of Accounting Diversity: Evidence from the European Union.' Journal of Accounting Research 32 (Supplement): 141-168. 
KELlER, E., AND H. P. MÖLLER. 1992. 'Einstufung von Bankbilanzen am Kapitalmarkt infolge von § 26a KWG.' Zeitschrift für Bankrecht und Bankwirtschaft 4: 169-183.

Keller, E., AND H. P. MÖLler. 1993. 'Die Auswirkungen der Zwischenberichterstattung auf den Informationswert von Jahresabschlüssen am Kapitalmarkt.' In Empirische Kapitalmarktforschung, Zeitschrift für betriebswirtschaftliche Forschung. Sonderheft 31. Eds. W. Bühler et al.: 35-60.

KIESO, D., AND J. WEYGANDT. 1995. Intermediate Accounting. 8th edn. New York et al.: Wiley.

KIRSCH, H.-J., M. DOHRN, AND J. WIRTH. 2002. 'Rechungslegungs- und Prüfungspraxis der DAX-100-Unternehmen - Bestandsaufnahme und Auswirkungen der EU-Verordnung zur Anwendung internationaler Rechnungslegungstandards.' Die Wirtschaftsprüfung 55: 1217-1231.

Kothari, S., AND R. SlOAN. 1992. 'Information in Prices about Future Earnings: Implications for Earnings Response Coefficients.' Journal of Accounting and Economics 21: 143-172.

KÜBLER, F. 1989. Unternehmensfinanzierung und Kapitalmarkt. Köln: Bank-Verl.$\mathrm{GmbH}$.

KÜTING, K., U. DÜRR, AND C. ZWIRNER. 2002. 'Internationalisierung der Rechnungslegung in Deutschland - Ausweitung durch die Unternehmen des SMAX ab 2002.' Kapitalmarktorientierte Rechnungslegung 2: 1-13.

LA Porta, R., F. LoPeZ-DE-Silanes, A. SchleIfer, AND R. Vishny. 1998. 'Law and Finance.' Journal of Political Economy 106 (6): 1113-1155.

LA Porta, R., F. LOPEZ-DE-Silanes, AND A. SCHLEIFER. 2002. 'What works in Securities Laws?' Working Paper. Harvard University.

LEUZ, C. 1996. Rechnungslegung und Kreditfinanzierung. Frankfurt am Main: Lang.

LEuZ, C. 2000. 'The Development of Voluntary Cash Flow Statements in Germany and the Influence of International Reporting Standards.' Schmalenbach Business Review 52 (April): 182-207.

LEUZ, C. 2003a. 'Proprietary versus Non-Proprietary Disclosures: Evidence from Germany.' In The Economics and Politics of Accounting: International Essays, eds. A. Hopwood et al. Oxford: Oxford University Press. Forthcoming.

LEUZ, C. 2003b. 'IAS versus U.S. GAAP: Information-Asymmetry-Based Evidence from Germany's New Market.' Journal of Accounting Research 41: 445-472.

LeuZ, C., AND R. VERRECCHIA. 2000. 'The Economic Consequences of Increased Disclosure.' Journal of Accounting Research 38. Supplement: 91-124.

Leuz, C., D. Deller, AND M. Stubenrath. 1998. 'An International Comparison of Accounting-Based Payout Restrictions in the United States, United Kingdom and Germany.' Accounting and Business Research 28 (Spring): 111-129.

LEUZ, C., D. NANDA, AND P. WysocKI. 2003. 'Earnings Management and Investor Protection: An International Comparison.' Journal of Financial Economics. Forthcoming. 
Loss, L., And J. Seligman. 1999. Securities Regulation, Vol. II. New York: Aspen Law \& Business.

McLeay, S., D. Ordelheide, AND S. Young. 2000. 'Constituent lobbying and its impact on the development of financial reporting regulations: evidence from Germany.' Accounting, Organizations and Society 25: 79-98.

MeEK, G., AND S. GRAY. 1989. 'Globalization of Stock Markets and Foreign Listing Requirements: Voluntary Disclosures by Continental-European Companies listed on the London Stock Exchange.' Journal of International Business Studies (Summer): 315-336.

MetCAlF, L. 1977. 'The Accounting Establishment: A Staff Study prepared by the Subcommittee on Reports, Accounting and Management of the Committee on Government Operations (excerpts).' In News Report, Journal of Accountancy 143 (March): 7-18.

Möller, H., AND E. Keller. 1999. 'Financial Reporting and the Stock Market in Germany.' In Empirical Research on the German Capital Market, eds. W. Bühler et al. Heidelberg: Physica: 135-148.

MOXTER, A. 1985. 'Das System der handelsrechtlichen Grundsätze ordnungsmäßiger Bilanzierung.' In Der Wirtschaftsprüfer im Schnittpunkt nationaler und internationaler Entwicklungen: Festschrift zum 60. Geburtstag von Prof. Dr. Klaus v. Wysock, ed. Gerhard Gross. Düsseldorf : IDW-Verlag: 17-28.

MOXTER, A. 1999. Bilanzrechtsprechung. 5th edn. Tübingen: Mohr.

MOXTER, A. 2003. Grundsätze ordnungsgemäßer Rechnungslegung. Düsseldorf: IDWVerlag.

NAUMANN, K.-P. 2000. 'Financial reporting enforcement mechanisms as an element of corporate governance in Germany and reflections on their further development.' The European Accounting Review 9: 655-672.

NOWAK, E. 2001a. 'Ermittlung der Eignung von Sachverhalten zur erheblichen Kursbeeinflussung bei Ad-hoc Mitteilungen: Eine empirische Untersuchung.' Zeitschrift für Bankrecht und Bankwirtschaft 13: 449-524.

NowAK, E. 2001b. 'Recent developments in German Capital Markets and Corporate Governance.' Journal of Applied Corporate Finance 14 (3): 35-48.

Ordelheide, D., AND D. Pfaff. 1994. European Financial Reporting - Germany. London: Routledge.

ORDELHEIDE, D. 1998. 'Wettbewerb der Rechnungslegungssysteme IAS, US-GAAP und HGB - Plädoyer für eine Reform des deutschen Bilanzrechts.' In Controlling und Rechnungswesen im internationalen Wettbewerb, eds. C. Börsig and A. Coenenberg. Stuttgart: Schäffer-Poeschel: 15-53.

ORDELHEIDE, D. 2001. 'Germany-Group Accounts.' In Transnational Accounting, eds. D. Ordelheide and KPMG. 2nd edn. Palgrave: New York: 1353-1449.

RAJAN, R., AND L. ZingaLeS. 1998. 'Financial dependence and growth.' American Economic Review 88: 559-587. 
SAUdAgaran, S., AND G. BIDDLE. 1992. 'Financial Disclosure Levels and Foreign Stock Exchange Listing Decisions.' Journal of International Financial Management and Accounting 4: 106-148.

SCHMIDT, P.-J. 1998. 'Disclosure and Auditing. A German Perspective.' In Comparative Corporate Governance, eds. K. J. Hopt et al. Oxford: Oxford University Press: 743-752.

SCHMIDT, R.H., AND G. SPINDLER. 2002. 'Complementarity, Path Dependence and Corporate Governance.' International Finance 5: 311-333.

SCHMIDT, R. H., AND M. TYRELL. 1997. 'Financial systems, corporate finance and corporate governance.' European Financial Management 3 : 333-361.

SCHWALBACH, J., AND U. GRAßHOFF. 1997. 'Managervergütung und Unternehmenserfolg.' Zeitschrift für Betriebswirtschaft 67: 203-217.

SEEGER, H. 1998. Insiderhandel am deutschen Aktienmarkt: eine empirische Untersuchung von Existenz und Erkennbarkeit. Frankfurt a. M.: Lang.

SIEGEL, S. 1985. 'A critical examination of state regulation of accounting principles.' Journal of Comparative Business and Capital Market Law 7: 317-331.

SPANHEIMER, J., AND C. KOCH. 2000. 'Internationale Bilanzierungpraxis in Deutschland - Ergebnisse einer empirischen Untersuchung der Unternehmen des DAX und MDAX sowie des Neuen Marktes.' Die Wirtschaftsprüfung 53: 301-309.

WatTS, R. L., AND J. L. Zimmerman. 1986. Positive Accounting Theory. Englewood Cliffs, N.J.: Prentice-Hall.

WÜSTEMANN, J. 1996. 'US-GAAP: Modell für das deutsche Bilanzrecht?' Die Wirtschaftsprüfung 49 (11): 421-431.

Wüstemann, J. 1999. Generally Accepted Accounting Principles. Berlin: Duncker \& Humblot.

WÜstemanN, J. 2001. 'Mängel bei der Abschlußprüfung: Tatsachenberichte und Analysen aus betriebswirtschaftlicher Sicht.' In Der Wirtschaftsprüfer als Element der Corporate Governance, ed. M. Lutter. Düsseldorf: IDW-Verlag.

WÜSTEMANN, J. 2002a. Institutionenökonomik und internationale Rechnungslegungsordnungen. Tübingen: Mohr.

Wüstemann, J. 2002b. 'Normdurchsetzung in der deutschen Rechnungslegung Enforcement nach dem Vorbild der USA.' Betriebs-Berater 57: 718-725. 


\section{APPENDIX}

This data is based on a more comprehensive survey on the frequencies of accounting regimes in Germany. For further information see Fischer et al. (2001), Glaum (2001), Kirsch et al. (2002), Küting et al. (2002), Leuz (2003b) and Spanheimer and Koch (2000).

Table 1

Applied Accounting Standards of Listed Companies in Germany as of January 1, 2002

\begin{tabular}{lccc}
\hline Market Segment & $\begin{array}{c}\text { Percentage of } \\
\text { Companies } \\
\text { Applying } \\
\text { German GAAP }\end{array}$ & $\begin{array}{c}\text { Percentage of } \\
\text { Companies } \\
\text { Applying }\end{array}$ & $\begin{array}{c}\text { Percentage of } \\
\text { Companies } \\
\text { Applying IAS } \\
\text { (IFRS) }\end{array}$ \\
\hline DAX 30 & US GAAP & \\
DAX 100 & $39 \%$ & $27 \%$ & $60 \%$ \\
M-DAX & $51 \%$ & $20 \%$ & $41 \%$ \\
NEMAX 50 & $0.0 \%$ & $16 \%$ & $33 \%$ \\
\hline
\end{tabular}

Note: See chapter 10 of this book for definitions of market segments.

Table 2

Number of German multinationals listed outside Germany (selected stock exchanges)

\begin{tabular}{lccc}
\hline Market Segment & $\begin{array}{c}\text { New York } \\
\text { (NYSE and } \\
\text { NASDAQ) } *\end{array}$ & London ** & Toronto *** \\
\hline 1995 & 0 & 7 & 8 \\
1998 & 11 & 8 & 8 \\
2000 & 19 & 9 & 6 \\
2002 & 23 & 9 & 5 \\
\hline
\end{tabular}

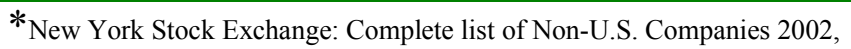
http://www.nyse.com/international/international.html, 30.10.2002, 9.00h.

Nasdaq: International Companies,

http://www.nasdaq.com/asp/NonUsOutput.asp?page $=$ G\&previousCount=0\&region=europe, $30.10 .2002,9.00 \mathrm{~h}$

** London Stock Exchange: International Companies,

http://www.londonstockexchange.com/international/WE/trigger.asp?filter=3\&submitted $=\& C N S=\& i P$ ageNum=1, 30.10.2002, 9.15h.

$* * *$ Tokyo Stock Exchange: Listed/delisted foreign companies,

http://www.tse.or.jp/english/listing/companies/transition.html, 30.10.2002, 9.30h
} 
Table 3

Applied Accounting Standards 1985 - 2002 in Germany DAX 100

\begin{tabular}{cccc}
\hline Year & $\begin{array}{c}\text { Percentage of } \\
\text { Companies } \\
\text { Applying } \\
\text { German GAAP }\end{array}$ & $\begin{array}{c}\text { Percentage of } \\
\text { Companies } \\
\text { Applying } \\
\text { US GAAP* }\end{array}$ & $\begin{array}{c}\text { Percentage of } \\
\text { Companies } \\
\text { Applying IAS } \\
(\text { IFRS) }\end{array}$ \\
\hline 1985 & $100 \%$ & $0 \%$ & $0 \%$ \\
1995 & $94 \%$ & $1 \%$ & $5 \%$ \\
1998 & $81 \%$ & $6 \%$ & $13 \%$ \\
2000 & $53 \%$ & $17 \%$ & $30 \%$ \\
2002 & $39 \%$ & $20 \%$ & $41 \%$ \\
\hline
\end{tabular}

Note: chapter 10 of this book for definitions of market segments.

* Including reconciliations from German GAAP

Table 4

Legal forms of business enterprises and accounting standards in 2000 (individual accounts) *

\begin{tabular}{lccc}
\hline Year & $\begin{array}{c}\text { Number of } \\
\text { Companies } \\
\text { Applying German } \\
\text { GAAP }\end{array}$ & $\begin{array}{c}\text { Number of } \\
\text { Companies Applying } \\
\text { US GAAP }\end{array}$ & $\begin{array}{c}\text { Number of } \\
\text { Companies Applying } \\
\text { IAS (IFRS) }\end{array}$ \\
\hline Private ltd. Company & 446.797 & 0 & 0 \\
Corporation & 5.526 & 0 & 0 \\
Sole proprietorship & 2.040 .713 & 0 & 0 \\
Business partnership & 364.967 & 0 & 0 \\
\hline & * Source: Statistisches Bundesamt, Wiesbaden
\end{tabular}

* Source: Statistisches Bundesamt, Wiesbaden 


\section{CFS Working Paper Series:}

\begin{tabular}{|c|c|c|}
\hline No. & Author(s) & Title \\
\hline 2003/07 & $\begin{array}{l}\text { Günter Coenen } \\
\text { Andrew Levin } \\
\text { Volker Wieland }\end{array}$ & $\begin{array}{l}\text { Data Uncertainty and the Role of Money as an } \\
\text { Information Variable for Monetary Policy }\end{array}$ \\
\hline 2003/08 & $\begin{array}{l}\text { Günter Coenen } \\
\text { Volker Wieland }\end{array}$ & $\begin{array}{l}\text { A Small Estimated Euro Area Model with } \\
\text { Rational Expectations and Nominal Rigidities }\end{array}$ \\
\hline 2003/09 & $\begin{array}{l}\text { Günter Coenen } \\
\text { Volker Wieland }\end{array}$ & $\begin{array}{l}\text { The Zero-Interest-Rate and the Role of the } \\
\text { Exchange Rate for Monetary Policy in Japan }\end{array}$ \\
\hline $2003 / 10$ & $\begin{array}{l}\text { Stefan Reitz } \\
\text { Frank Westerhoff }\end{array}$ & $\begin{array}{l}\text { Nonlinearities and Cyclical Behavior: } \\
\text { The Role of Chartists and Fundamentalists }\end{array}$ \\
\hline $2003 / 11$ & $\begin{array}{l}\text { Stefan Reitz } \\
\text { Ralf Ahrens }\end{array}$ & $\begin{array}{l}\text { Heterogeneous Expectations in the Foreign } \\
\text { Exchange Market Evidence from the Daily } \\
\text { Dollar/DM Exchange Rate }\end{array}$ \\
\hline $2003 / 12$ & Klaus Adam & $\begin{array}{l}\text { Optimal Monetary Policy with } \\
\text { Imperfect Common Knowledge }\end{array}$ \\
\hline $2003 / 13$ & $\begin{array}{l}\text { Günter Coenen } \\
\text { Athanasios Orphanides } \\
\text { Volker Wieland }\end{array}$ & $\begin{array}{l}\text { Price Stability and Monetary Policy Effectiveness } \\
\text { when Nominal Interest Rates are Bounded at Zero }\end{array}$ \\
\hline $2003 / 14$ & Raimond Maurer & $\begin{array}{l}\text { Institutional Investors in Germany: Insurance } \\
\text { Companies and Investment Funds }\end{array}$ \\
\hline $2003 / 15$ & $\begin{array}{l}\text { Daniel Schmidt } \\
\text { Mark Wahrenburg }\end{array}$ & $\begin{array}{l}\text { Contractual Relations between European VC- } \\
\text { Funds and Investors: The Impact of Reputation } \\
\text { and Bargaining Power on Contractual Design }\end{array}$ \\
\hline $2003 / 16$ & $\begin{array}{l}\text { Christian Leuz } \\
\text { Jens Wüstemann }\end{array}$ & $\begin{array}{l}\text { The Role of Accounting in the German Financial } \\
\text { System }\end{array}$ \\
\hline $2003 / 17$ & Erik Theissen & Organized Equity Markets in Germany \\
\hline
\end{tabular}

Copies of working papers are available at the Center for Financial Studies or can be downloaded (http://www.ifk-cfs.de). 